\title{
Metallothionein and bZIP Transcription Factor Genes from Velvetleaf and Their Differential Expression Following Colletotrichum coccodes Infection
}

\author{
Amélie L. Dauch and Suha H. Jabaji-Hare
}

Department of Plant Science, Macdonald Campus of McGill University, 21,111 Lakeshore Rd., Ste-Anne-de-Bellevue, Québec, H9X 3V9, Canada.

Accepted for publication 18 May 2006.

\begin{abstract}
Dauch, A. L., and Jabaji-Hare, S. H. 2006. Metallothionein and bZIP transcription factor genes from velvetleaf and their differential expression following Colletotrichum coccodes infection. Phytopathology 96:11161123 .

Colletotrichum coccodes is a biocontrol agent of velvetleaf (Abutilon theophrasti), a noxious weed of corn and soybean. Metallothioneins (MTs) and basic region/leucine zipper motif (bZIP) are heavy-metal-binding proteins and transcription factors, respectively, that have been related to several plant processes, including the responses of plants to pathogen attack. Previous investigation of the determinants involved in the velvetleaf-C. coccodes interaction had shed light on particular plant and fungal genes expressed in this pathosystem. Here, we report on the temporal

expression patterns of two distinct types (2 and 3) of MT and bZIP transcription factor genes in velvetleaf leaves following infection with C. coccodes using quantitative reverse-transcription polymerase chain reaction. Gene expression ratios were significantly upregulated 1 day after infection (DAI), a time at which velvetleaf leaves appeared symptomless. At 2 DAI, bZIP and type 3 MT expression ratios dropped to levels significantly lower than those estimated for noninfected plants. Necrotic symptoms appeared 5 DAI and increased with time, during which gene expression levels were maintained either below or at levels observed in the control. These findings indicate that $C$. coccodes altered the expression of type 2 and 3 MT and bZIP genes. In addition, this is the first report on induction of a type 3 MT in plants in response to a pathogen attack.
\end{abstract}

Plant metallothioneins (MTs) are small, highly conserved cysteine-rich heavy-metal-binding proteins, typically classified into four categories (types 1 to 4 ) based on their amino acid sequence and cysteine residue arrangement (13). Plant MT gene expression is regulated by various factors, including metal ions, developmental stages, symbiotic interaction, and various stress responses $(13,32)$. For instance, zinc induced MT gene expression in poplar (25), whereas copper reduced the levels of tobacco MT (40). MT gene expression also was induced in senescing tissues of species of Quercus (30), Populus (6), and Ipomoea (22) and during actinorhizal symbiosis (26). Stresses such as wounding and virus infection were shown to induce the expression of MT in tobacco (10), while differential expression of MT was detected in Arabidopsis following infection of compatible and incompatible strains of Peronospora spp. (8). In this respect, plant MTs have been proposed to function as reactive oxygen species (ROS) scavengers $(3,44)$ that protect plant DNA from oxidative damage caused by deleterious free radicals liberated during the oxidative burst $(11,31)$.

Although the majority of the MT genes expressed belong to type 2 (13), types 1,3 , and 4 MT genes also have been reported to be involved in various plant processes. For example, transcript accumulation of type 1 MT was shown in various organs and in response to pathogen attack (8). High levels of type 3 MT transcripts were found in ripening fruit $(12,13,35)$ and in senescing plant leaves (7), whereas the expression of type 4 MT genes seems to remain confined in maturing seed $(20,43,48)$. Despite

Corresponding author: S. Jabaji-Hare; E-mail address: suha.jabaji-hare@mcgill.ca

DOI: 10.1094/PHYTO-96-1116

(C) 2006 The American Phytopathological Society the vast majority of reports on spatial MT gene expression, there is no clear consensus on MT gene localization in specific plant organs (13).

In plants, basic region/leucine zipper motif (bZIP) transcription factors are members of a large family of signaling components that regulate gene expression of several biological processes, including pathogen defense (23). As with MTs, members of the bZIP transcription factor family are induced in senescing leaves of tobacco (46) and Arabidopsis (9,29), as well as in plants responding to pathogen attack $(24,27)$. In addition, bZIP transcription factors have been reported to regulate the expression of at least one type of MT gene in humans (28), an observation that has not been made in plants.

Colletotrichum coccodes (isolate DAOM 183088) is a hostspecific pathogen of velvetleaf (Abutilon theophrasti Medik), a notorious broadleaf weed in soybean and corn cropping systems (41). Typically, this isolate causes gray-brown foliar lesions on velvetleaf, leading to rapid senescence and premature shedding of leaves. Because of its restricted host range, $C$. coccodes has been considered a potential mycoherbicide for velvetleaf, and continued research to enhance this weed-control strategy has focused on laboratory and field studies targeted at optimization of inoculum production (47), mode of application $(21,45)$, efficacy $(1,5)$, molecular detection and quantification methodologies $(14,15)$, and partial elucidation of the plant's defense mechanism (2). Despite all of these advances, studies on the characterization and analysis of gene expression during velvetleaf-C. coccodes interaction are still lacking.

Characterization of velvetleaf stress response to $C$. coccodes infection is crucial to the development of an efficient mycoherbicide weed-control strategy. This led us to initiate a large-scale expressed sequence tag (EST) study, and we characterized 139 plant ESTs that were preferentially induced in response to C. coc- 
codes infection. Among them, a type 3 MT and a bZIP transcription factor were identified and their induction in velvetleaf leaves upon $C$. coccodes infection was confirmed (A. L. Dauch and S. H. Jabaji-Hare, unpublished data). Based on our findings and the involvement of MT and bZIP transcription factors in plant stress and senescence, the current study was conducted to investigate whether MT-encoding genes and the bZIP transcription factor respond directly to $C$. coccodes infection. To do so, we monitored the temporal gene expression ratios of type 2 and type 3 MT and bZIP transcription factor in leaves of velvetleaf infected with $C$. coccodes using quantitative reverse-transcription polymerase chain reaction (QRT-PCR).

\section{MATERIALS AND METHODS}

Biological material and growth conditions. C. coccodes (isolate DAOM 183088), deposited at the Biosystematics Research Institute (Ottawa, ON, Canada), was cultured on potato dextrose agar (PDA; Becton Dickinson Microbiology Systems, Sparks, MD) for 1 week at $28^{\circ} \mathrm{C}$ in the dark. Conidial production was initiated by transferring five agar plugs into $600 \mathrm{ml}$ of modified Richard medium (MRM) (16) and incubating them at $24^{\circ} \mathrm{C}$ with agitation $(200 \mathrm{rpm})$ for 7 days. The conidia were harvested through filtration and centrifuged at $4{ }^{\circ} \mathrm{C}$ for $10 \mathrm{~min}$ at $6,000 \times g$. The conidial pellet was resuspended and adjusted with $\mathrm{ddH}_{2} \mathrm{O}$ to a final concentration of $10^{9}$ conidia/ml, using a hemacytometer.

Velvetleaf (A. theophrasti Medik.) seeds were placed in 100by-15-mm petri dishes on Whatman papers no. 1, moistened with $4 \mathrm{ml}$ of distilled water, and pregerminated in the dark for 3 days. Two pregerminated seeds were planted in Cone-tainers (Stuewe and Sons, Corvallis, OR) of 164-ml capacity. Prior to use, the Cone-tainers were surface sterilized for $45 \mathrm{~min}$ in a $3 \%$ solution of sodium hypochlorite, rinsed with distilled water, and filled with moist, nonsterile PROMIX (Promix Inc., Rivière du Loup, QC, Canada). The Cone-tainers were placed on racks, randomized, and placed in growth chambers with conditions adjusted to 24 and $18^{\circ} \mathrm{C}$ for 10 and $14 \mathrm{~h}$ (day and night), respectively, with a light intensity of $300 \mu \mathrm{M} / \mathrm{m}^{2}$. One week after seeding, plants were thinned to leave one seedling per Cone-tainer. Plants were watered and fertilized 2 weeks after the initial seeding with $20 \mathrm{ml}$ ( $3 \mathrm{~g} /$ liter) of solution of 20:20:20 (N:P:K) until 4 weeks old (fiveleaf stage). Spraying of velvetleaf plants was performed in a spray chamber (Research Instrument MFG Co. Ltd., Guelph, ON, Canada) to ensure uniform coverage of the leaves. The sprayed plants were placed in a dew chamber $\left(90 \%\right.$ humidity, $\left.24^{\circ} \mathrm{C}\right)$ for $18 \mathrm{~h}$ to maximize fungal infection. All plants received $C$. coc- codes at a constant rate of $10^{9}$ conidia $/ \mathrm{ml}\left(50 \mathrm{ml} / \mathrm{m}^{2}\right)$, whereas uninfected plants received $\mathrm{ddH}_{2} \mathrm{O}$ (mock treatment). There were three replicates per treatment; each replicate consisted of one Cone-tainer containing one plant. The third leaf from each plant was excised at the base of the petiole at five different time points $(1,2,5,7$, and 14 days after infection [DAI]) and immediately flash-frozen in liquid nitrogen $(\mathrm{N})$.

Isolation of genomic DNA and RNA, reverse-transcription and conventional PCR. Genomic DNA (gDNA) from C. coccodes was isolated from $20 \mathrm{mg}$ of freeze-dried 12-day-old mycelial mats as previously described (14). Total gDNA from velvetleaf leaves was extracted using the Qiagen DNeasy Plant Mini-Kit (Qiagen, Mississauga, ON, Canada) following the manufacturer's protocol, except that all pipetting steps were carried out on ice, centrifugation steps were performed at $4{ }^{\circ} \mathrm{C}$, and an additional washing step was incorporated. DNA isolated from all biological material were estimated quantitatively and qualitatively by spectrophotometry, and run on $1 \%$ agarose gels (1× Tris-acetate EDTA [TAE]) to verify the absence of DNA degradation.

For RNA extraction, leaf samples were ground in liquid $\mathrm{N}$ with the addition of $0.5 \mathrm{~g}$ of $\mathrm{NaCl}$ and $0.33 \mathrm{~g}$ of polyvinyl-polypyrrolidone to prevent the mucilaginous material from interfering in the nucleic acid extraction processes. Total fungal and plant RNA were extracted from $100 \mathrm{mg}$ of conidial powder and $100 \mathrm{mg}$ of leaf tissue, respectively, with the RNeasy Plant Mini kit (Qiagen) with the following modifications: two lilac columns that were used for filtration were loaded with $700 \mu$ of RLT buffer (guanidine-isothiocyanatebase buffer) containing resuspended fungal or plant powder, and their precipitate was pooled in a single pink column (RNA-binding) for each sample unit. RNA extracts were treated with TURBO DNase (Ambion Inc., Austin, TX) to remove potential DNA contaminants, and the integrity of the isolated nucleic acids was checked on $1.2 \%$ agarose denaturing formaldehyde gels. The absence of DNA contamination in the total RNA extracts also was verified by PCR amplification of total RNA with the $\mathrm{VvactF} / \mathrm{R}$ primer set (Table 1), which amplifies a segment of the actin gene from velvetleaf. Reverse transcription of $500 \mathrm{ng}$ of DNA-free RNA into cDNA was accomplished with the QuantiTect Reverse Transcription kits (Qiagen).

Conventional PCR was performed in an Applied Biosystems 9600 thermocycler (Foster City, CA) as follows: the reaction mix $(25 \mu \mathrm{l})$ consisted of $2 \mu \mathrm{l}$ of RNA template, $0.2 \mu \mathrm{M}$ each primer, $2.5 \mu \mathrm{l}$ of $10 \times$ buffer $(200 \mathrm{mM}$ Tris- $\mathrm{HCl}, \mathrm{pH} 8.4$, and $500 \mathrm{mM}$ $\mathrm{KCl}$ ), 0.5 unit of $\mathrm{Taq}$ polymerase (Invitrogen, Burlington, ON, Canada), and $200 \mathrm{nM}$ each dNTP (Invitrogen). Reactions were

TABLE 1. Polymerase chain reaction (PCR) primer characteristics ${ }^{\mathrm{a}}$

\begin{tabular}{|c|c|c|c|c|c|c|c|}
\hline Target gene ${ }^{b}$ & Primer & $\begin{array}{l}\text { Size } \\
\text { (bp) }\end{array}$ & Sequence $\left(5^{\prime}-3^{\prime}\right)$ & $\begin{array}{l}\text { Primer } \\
\operatorname{Tm}\left({ }^{\circ} \mathrm{C}\right)^{\mathrm{c}}\end{array}$ & $\begin{array}{c}\text { Real-time } \\
\text { PCR } \\
\text { efficiency }\end{array}$ & $\begin{array}{l}\text { Amplicon } \\
\text { size }(b p)^{d}\end{array}$ & $\begin{array}{l}\text { Amplicon } \\
\operatorname{Tm}\left({ }^{\circ} \mathrm{C}\right)\end{array}$ \\
\hline Type 2 MT & $\begin{array}{l}\text { VvMet23F } \\
\text { VvMet23R }\end{array}$ & $\begin{array}{l}23 \\
20\end{array}$ & $\begin{array}{l}\text { GAGTTCTCAGTTGTCTCGGCAA } \\
\text { GTCTTGCTGTGGTGGAAACT }\end{array}$ & $\begin{array}{l}68 \\
60\end{array}$ & 1.65 & 130 & 82.3 \\
\hline Type 3 MT & $\begin{array}{l}\text { AtMt3F } \\
\text { AtMt3R }\end{array}$ & $\begin{array}{l}19 \\
20\end{array}$ & $\begin{array}{l}\text { GTGCGTGAAGCAAGGAAAC } \\
\text { TCCACACTTGCAATCGTTCT }\end{array}$ & $\begin{array}{l}58 \\
58\end{array}$ & 1.87 & 106 & 79.6 \\
\hline bZIP transcription factor & $\begin{array}{l}\text { VvbZIP3F } \\
\text { VvbZIP3R }\end{array}$ & $\begin{array}{l}20 \\
20\end{array}$ & $\begin{array}{l}\text { CTGAGGAGATGCTTGCTGGA } \\
\text { TGGATGGTAATGGTGGGTGA }\end{array}$ & $\begin{array}{l}62 \\
60\end{array}$ & 1.56 & 120 & 81.7 \\
\hline$\beta$-Tubulin & $\begin{array}{l}\text { Vvtub3F } \\
\text { VvTub3R }\end{array}$ & $\begin{array}{l}20 \\
20\end{array}$ & $\begin{array}{l}\text { TCCCAACAACGTGAAATCAA } \\
\text { CATCCATTCCTTCCСCTGTA }\end{array}$ & $\begin{array}{l}56 \\
60\end{array}$ & 1.75 & 200 & 81.3 \\
\hline Actin & $\begin{array}{l}\text { VvactF } \\
\text { VvactR }\end{array}$ & $\begin{array}{l}18 \\
20\end{array}$ & $\begin{array}{l}\text { AATGGCCGATGGTGAGGA } \\
\text { TCCTTCTGACCCATCCCAAC }\end{array}$ & $\begin{array}{l}56 \\
62\end{array}$ & na & $159\left(250^{\mathrm{e}}\right)$ & na \\
\hline
\end{tabular}

a na $=$ Not applicable.

${ }^{\mathrm{b}} \mathrm{MT}=$ metallothionein and $\mathrm{bZIP}=$ basic region/leucine zipper motif.

c $\mathrm{Tm}$ is provided as $\mathrm{Tm}=2 \times(\mathrm{A}+\mathrm{T})+4 \times(\mathrm{C}+\mathrm{G})$.

d Amplicon size on cDNA; approximate size.

e Amplicon size on genomic DNA. 
prepared on ice and cycled for $3 \mathrm{~min}$ at $94^{\circ} \mathrm{C} ; 30$ cycles of $1 \mathrm{~min}$ at $94^{\circ} \mathrm{C}, 1 \mathrm{~min}$ at $56^{\circ} \mathrm{C}$, and $1 \mathrm{~min}$ at $72^{\circ} \mathrm{C}$; and a final extension step at $72^{\circ} \mathrm{C}$ for $10 \mathrm{~min}$. A positive and a negative control containing $2 \mu \mathrm{l}$ of velvetleaf gDNA $(10 \mathrm{ng} / \mu \mathrm{l})$ and $\mathrm{ddH}_{2} \mathrm{O}$, respectively, were included in each run. PCR products were resolved on $1 \%$ agarose gels (1× TAE) with a Gene Ruler 100-bp DNA Ladder (Invitrogen), stained with ethidium bromide, and pictures were recorded by a gel print 2000i documentation system (BIOCAN Scientific, Mississauga, ON, Canada).

Primer design. Primer pairs for three target genes and one housekeeping gene (HKG) were designed with the software Primer 3 (36), submitted to Nucleotide Blast at NCBI to confirm specificity (Table 1), and custom synthesized by AlphaDNA (Montréal, QC). The type 2 MT primers (VvMet23F/R) were designed based on the sequences of the type 2 MT gene from Gossypium hirsutum (GenBank accession nos. DT051903, DT051624, and AI732023). The primer sets for type $3 \mathrm{MT}$ (AtMt3F/R) and bZIP transcription factor (VvbZIP3F/R) were designed based on ESTs previously identified from a subtracted library constructed from velvetleaf-C. coccodes interaction (GenBank accession nos. DV767807 to DV767846 and DV970112 to DV970114 for type 3 MT, and DV767736 for bZIP). The identity of each of the target sequences was inferred by BLAST (4) (blastn and blastx) analysis conducted through the web interface at NCBI on sequences from Viridiplantae. Type 3 MT and bZIP sequences were identified by sequence similarity to G. hirsutum MT (GenBank accession no. AAW47577) and Arabidopsis thaliana bZIP transcription factor (GenBank accession nos. AAG25727 and AAG25728). Conceptual amino acid sequences were predicted using the Expert Protein Analysis System translate tool (19).

The HKG tubulin was amplified with the primer pair Vvtub3F/R that was designed based on a $G$. hirsutum $\beta$-tubulin sequence (GenBank accession no. AF487511). Several primer pairs targeting other potential velvetleaf HKGs, such as actin, 4-hydroxyphenylpyruvate dioxygenase (HPPD), and RNA polymerase, were also designed and products amplified using conventional RT-PCR, but were found unreliable during real-time QRT-PCR optimization. The actin gene primers, used to check for DNA contamination of RNA extracts, were designed based on Malva pusilla actin gene sequence (GenBank accession no. AF112538). They amplified products of 159 and $250 \mathrm{bp}$ from velvetleaf cDNA and gDNA, respectively.

All primers were tested on velvetleaf and $C$. coccodes gDNA and cDNA in conventional PCR and RT-PCR assays, respectively, followed by gel electrophoresis to confirm the plant origin of the amplified products. Melting point analyses were performed systematically at the end of the real-time PCR to confirm the amplification of a unique product for each of the target and housekeeping genes.

Expression analysis by real-time QRT-PCR. Real-time QRTPCR was performed for each of the target genes (type 2 MT, type 3 MT, and bZIP) and the HKG ( $\beta$-tubulin) in a Mx3000p thermocycler (Stratagene, La Jolla, CA). Each real-time PCR reaction mix (final volume of $20 \mu \mathrm{l}$ ) consisted of $10 \mu \mathrm{l}$ of Brilliant SYBR Green master mix (Stratagene), $125 \mathrm{nM} \mathrm{VvMet23F/R}$ (type $2 \mathrm{MT}$ ), $200 \mathrm{nM}$ AtMt3F/R (type $3 \mathrm{MT}$ ), $175 \mathrm{nM}$ VvbZIP3F/R (bZIP transcription factor), or $275 \mathrm{nM} \mathrm{Vvtub3F/R}$ ( $\beta$-tubulin) primers, $30 \mathrm{nM}$ ROX reference dye (Stratagene), and $4 \mu \mathrm{l}$ of template $(1 / 20$ th diluted of cDNA from velvetleaf inoculated with $C$. coccodes or mock-treated plants) or $4 \mu \mathrm{l}$ of $\mathrm{ddH}_{2} \mathrm{O}$ (negative control). Thermocycling was performed at an initial denaturation temperature of $95^{\circ} \mathrm{C}(10 \mathrm{~min})$, followed by 40 to 50 cycles at $95^{\circ} \mathrm{C}(30 \mathrm{~s}), 58^{\circ} \mathrm{C}$ (for type $2 \mathrm{MT}$ and tubulin primer sets), or $59^{\circ} \mathrm{C}$ (for type $3 \mathrm{MT}$ ) and bZIP transcription factor primer sets $)(15 \mathrm{~s}), 72^{\circ} \mathrm{C}\left(30 \mathrm{~s}, 2.5^{\circ} \mathrm{C} / \mathrm{s}\right)$. Fluorescence data was collected at each cycle at $77^{\circ} \mathrm{C}$ (for type $3 \mathrm{MT}$ primer set), $78^{\circ} \mathrm{C}$ (for $\beta$-tubulin and bZIP primer sets), or $80^{\circ} \mathrm{C}$ (for type $2 \mathrm{MT}$ primer set) and lasted $11 \mathrm{~s}$. Finally, a melting curve was generated by programming the thermocycler to reach $95^{\circ} \mathrm{C}(60 \mathrm{~s}), 55^{\circ} \mathrm{C}$ $\left(30 \mathrm{~s}, 2.5^{\circ} \mathrm{C} / \mathrm{s}\right)$, and $95^{\circ} \mathrm{C}\left(0 \mathrm{~s}, 0.1^{\circ} \mathrm{C} / \mathrm{s}\right)$. Data generated by realtime RT-PCR were estimated using Stratagene analysis software. Each run included a negative control and was repeated two times on two different days. Data were presented as averages of three biological replicates and two technical replicates.

Data quantification. Expression of the type $2 \mathrm{MT}$, type $3 \mathrm{MT}$, and bZIP genes was normalized against the expression of the HKG tubulin. Relative expression ratios were calculated for the three target genes in velvetleaf inoculated with $C$. coccodes (sample) versus the controls (mock treated) at 1, 2, 5, 7, and 14 DAI using equation 1 (33) (described below). $E_{\text {target }}$ and $E_{\text {ref }}$ represent the PCR amplification efficiencies for target and housekeeping genes, respectively, and were calculated from equation 2 (33) in which $\mathrm{RnB}$ and $\mathrm{RnA}$ are two fluorescence levels taken during the exponential phase at two crossing points (CPs), CPB and CPA. Amplification efficiencies for each gene first were calculated for all individual samples of the run and then averaged for each gene. $\Delta \mathrm{CP}_{\text {target }}$ is the $\mathrm{CP}$ deviation of control - sample of each target gene and $\Delta \mathrm{CP}_{\text {ref }}$ is the $\mathrm{CP}$ deviation of control sample of the HKG ( $\beta$-tubulin).

$$
\begin{gathered}
\text { Ratio }=\left(\mathrm{E}_{\text {target }}\right)^{\Delta \mathrm{CP}}{ }_{\text {target }}(\text { control }- \text { sample }) /\left(\mathrm{E}_{\text {ref }}\right)^{\Delta \mathrm{CP}} \text { ref }(\text { control - sample }) \\
\mathrm{E}=(\mathrm{RnB} / \mathrm{RnA})^{\wedge(1 / \mathrm{CPB}-\mathrm{CPA})}
\end{gathered}
$$

The fold change of each target gene was tested for significant difference between treatments using one-way analysis of variance in the Statistical Analysis System (37). Treatment mean comparisons at each time point were made using the least significant difference test at $P<0.05$ level.

\section{RESULTS}

MT and bZIP gene sequences from Abutilon theophrasti. MT type 3 cDNAs contain 180-bp open reading frames (ORFs) encoding 60 amino acids with a predicted molecular mass of 6,635 Da. Type $3 \mathrm{MT}$ proteins are characterized by four conserved cysteine residues at the $\mathrm{N}$-terminal end, the first three being part of a conserved domain arranged as Cys-Gly-Asn-CysAsp-Cys, and six cysteine residues in the $\mathrm{C}$-terminal cysteine-rich domain arranged as Cys-Xaa-Cys (Fig. 1B). By comparison with other plant MT sequences, velvetleaf type $3 \mathrm{MT}$ was found more similar to a Gossypium sp. (71\% identity), another Malvaceaeous plant, and to an Actinidia sp. (59\% identity), than to Oryza spp., Arabidopsis, or poplar type 3 MT sequences.

Despite the fact that the complete ORF of type 2 MT could not be obtained, the predicted amino acid composition showed motifs that undoubtedly identify the sequence as a type 2 MT. Seven conserved cysteine residues are located in the N-terminal end that begin with the conserved motif MSCCGGNCGCGS, characteristic of this type of MT (Fig. 1A) (13).

The ESTs for bZIP transcription factor (GenBank accession nos. DV767735 and DV767736) are 100\% identical to each other and lack the $\mathrm{N}$-terminal coding sequence. Based on the available C-terminal translated sequence, velvetleaf bZIP shares 29 and 46\% identity with Arabidopsis thaliana BZ02H1 (GenBank accession no. AAG25727) and BZ02H2 (GenBank accession no. AAG25728) bZIP proteins, respectively (data not shown). In addition, the 118 amino-acid-deduced sequence of velvetleaf bZIP transcription factor suggests the presence of two casein kinase II phosphorylation sites, as in the bZIP transcription factor proteins of Arabidopsis.

Quantification of target gene and the HKG transcripts. Using primers specifically developed for each of the three plant target genes and for the HKG $\beta$-tubulin (Table 1), the amplification of velvetleaf cDNA (Fig. 2A, C, E, and G) showed single expected amplicons with their respective melting temperatures 
(Fig. 2B, D, F, and H; Table 1) and with expected putative sizes (Fig. 3; Table 1). Prior to reverse transcription of total RNA to cDNA, all RNA samples were treated with RNase-free DNase, tested for the absence of DNA contamination by PCR using primers targeting the actin gene of velvetleaf (Table 1), and found to be DNA free. Depending on the gene, titers as low as 10 ag of target gene fragment could be reproducibly detected using SYBR Green chemistry (data not shown). Amplification plots were highly reproducible between technical replicates as indicated by almost identical cycle thresholds with standard deviation values ranging between 0.1 and 0.2 , and fluorescence data from negative controls containing no templates always remained below the detection threshold (Fig. 2A, C, E, and G; data not shown). Primer dimers $\left(\mathrm{Tm}=77^{\circ} \mathrm{C}\right)$ occasionally were detected in the negative control when using type 2 MT primers, although this never occurred in the samples (Fig. $2 \mathrm{C}$ and D). Tubulin and bZIP primers also sporadically generated primer dimers $(\mathrm{Tm}=74.5$ and $74^{\circ} \mathrm{C}$, respectively) (Fig. $2 \mathrm{~B}$ and $\mathrm{H}$ ) during PCR amplification of samples or control; however, measurements of fluorescence was performed systematically at $78^{\circ} \mathrm{C}$, a temperature at which potential primers dimers are denatured.

Temporal quantification of genes during disease development. Compared with uninfected plants, the expression ratios of the three target genes significantly $(P<0.05)$ changed in response to $C$. coccodes infection (Fig. $4 \mathrm{~A}$ to $\mathrm{C}$ ). The expression ratios were significantly $(P<0.05)$ upregulated by 8 -fold for type $2 \mathrm{MT}$, 16-fold for type $3 \mathrm{MT}$, and 4-fold for bZIP transcription factor 1 day after infection (Fig. 4A to C), a time period at which velvetleaf leaves appeared symptomless (Fig. 4D). Although the leaves still showed no visual symptoms after 2 days of infection (Fig. 4D), the expression ratios of type $3 \mathrm{MT}$ and bZIP transcription factor significantly dropped $(P<0.05)$ by two- and sixfold, respectively, below the expression ratio of control plants (Fig. 4B and C). Necrotic lesions became visible 5 DAI and increased with time (Fig. 4D), during which the expression ratios varied depending on the gene. The expression of bZIP-encoding genes consistently remained downregulated $5 \mathrm{DAI}$ and onward compared with uninfected leaves (Fig. 4C). In contrast, the expression ratios of types 2 and 3 MT transcripts showed a similar pattern of induction 5 and 7 DAI, followed by a drop of 1.5 -fold at 14 DAI. However, these differences were not significant $(P>0.05)$ compared with the control plants (Fig. 4A and B).

\section{DISCUSSION}

We studied the temporal gene expression of MT and bZIP transcription factor during the interaction between velvetleaf and the pathogenic biocontrol agent $C$. coccodes. The choice of these genes was based on a previous expression profiling study using high-throughput microarray analyses in which type 3 MT and bZIP transcription factor genes were induced in response to $C$. coccodes infections (unpublished data).

In this study, we have characterized velvetleaf cDNA encoding two types of MT. This is the first investigation of the occurrence of MTs in velvetleaf in response to pathogen attack. Based on the arrangement of cysteine residues, the deduced polypeptide can be classified as a class II type 2 and type 3 MT-like protein. Like other plant MT-like proteins, velvetleaf MT proteins are encoded by a small gene family distributed across different chromosomes, at least in Arabidopsis, Oryza, and Lycopersicon spp. (13). Although we did not obtain the full-length sequence of the velvetleaf bZIP gene, the cDNA sequence was found most similar to Arabidopsis bZIP genes that belong to group $\mathrm{C}$ of the bZIP superfamily. Protein members of this group have been linked to abiotic stress responses (42) and pathogen attack (17).

Several factors that could have affected the accuracy of MT and bZIP gene quantification were carefully controlled when conducting the experiments: (i) the design of gene-specific primers based on velvetleaf and Gossypium sequences deposited in the GenBank database; (ii) statistical validation of the HKG $\beta$-tubulin, whose expression remained constant among treatments $(P<0.05)$; (iii) individual QRT-PCR efficiencies for target and housekeeping genes were estimated on a sample-per-sample basis (33) in order to take into account inherent sample and PCR efficiency variations; and (iv) the application of a mathematical model combined with statistical analysis that accounts for both differences in amplification efficiencies and cycle threshold numbers (33).

In this study, substantial upregulation of type 2 MT-encoding genes in response to $C$. coccodes is in agreement with previous studies, in which overexpression of plant type 2 MT has been reported in tobacco-virus and potato-Phytophthora infestans pathosystems (8). Interestingly, our results indicate that significant overexpression of velvetleaf type 3 MT transcripts occurred 1 day after infection of velvetleaf leaves by $C$. coccodes. The very high expression ratio of type $3 \mathrm{MT}$ in this study represents the

\section{A Metallothionein type 2}

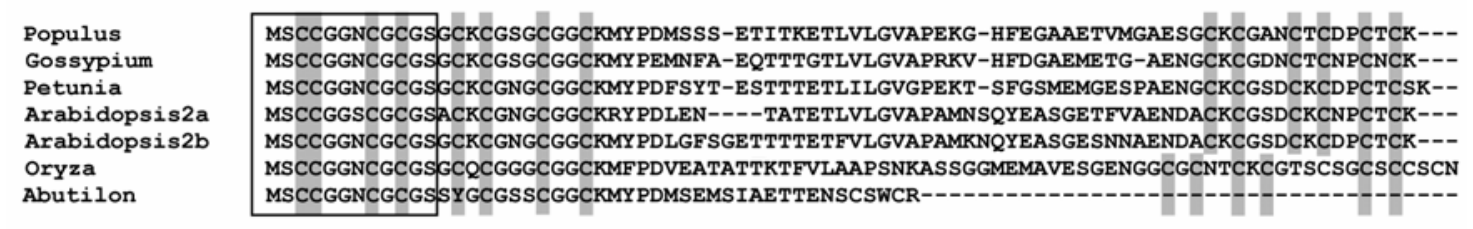

\section{B Metallothionein type 3}
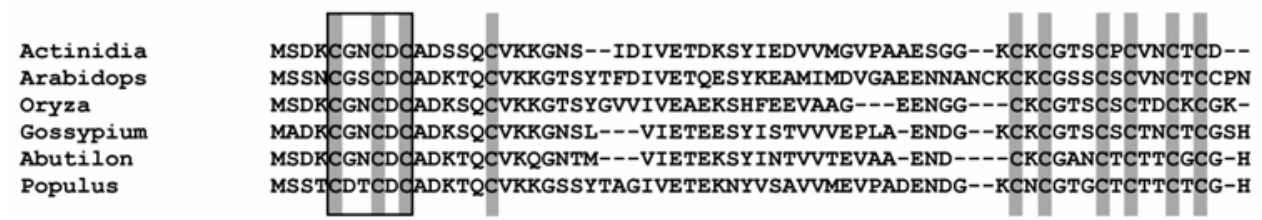

Fig. 1. Multiple alignment of velvetleaf (Abutilon theophrasti) A, type 2 and B, type 3 metallothionein (MT) amino acid sequences with other plant MT amino acid sequences. A, Type 2: Populus balsamifera subsp. trichocarpa $\times$ P. deltoides (GenBank accession no. AAT02524), Gossypium hirsutum (DT051624), Petunia hybrida (AAG39645), Arabidopsis thaliana MT2A (P25860), A. thaliana MT2B (NP_195858), and Oryza sativa (P93433). B, Type 3: Actinidia deliciosa (P43389), Arabidopsis thaliana (AAB67234), O. sativa (AAB53811), G. hirsutum (AAW47577), and Populus balsamifera subsp. trichocarpa $\times$ P. deltoids (AAT02527). Conserved cysteine residues are shown in gray boxes. Conserved motifs for each type are boxed with a solid line. 
first report that type $3 \mathrm{MT}$ in plants is inducible in response to pathogen attack. Although this was highly unexpected, because upregulation of plant type 3 MT so far has been observed as part of senescence-related responses in plants $(6,7)$, its overexpression could be related to its regulation by ethylene, a regulator of innate immunity, stress, and senescence responses (18,39). Disease caused by $C$. coccodes on velvetleaf involves the formation of necrotic senescent-like lesions that begin to appear on the leaves 5 DAI, followed by complete senescence after 14 days. The tem-

poral but differential expression of type 3 and type 2 MT over 14 days of infection might represent a combined response of the plant to pathogen attack and to the process of leaf senescence. In agreement with this observation, Quirino and colleagues demonstrated that a diverse range of genes, including those linked to the plant's defense response, were expressed during leaf senescence of Arabidopsis thaliana (34).

In this study, an important decline in expression ratio of type 3 MT, and to a lesser extent of type 2 MT, were observed 2 DAI,
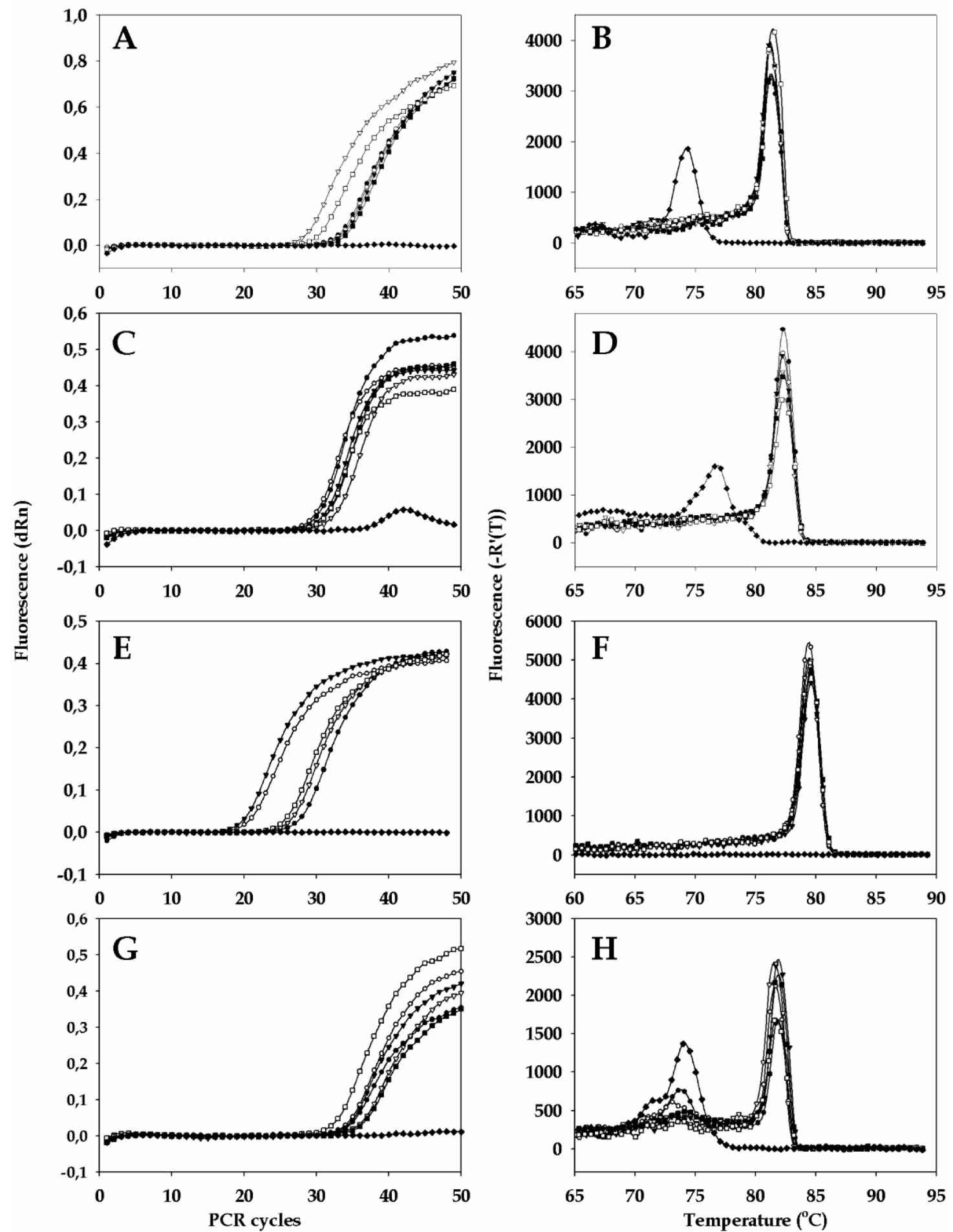

Fig. 2. Real-time quantitative reverse-transcription polymerase chain reaction quantification example of $\beta$-tubulin, metallothionein (MT) type 2, type 3 , and basic region/leucine zipper motif (bZIP) transcription factor genes: A and B, $\beta$-Tubulin; $\mathbf{C}$ and D, type 2 MT; $\mathbf{E}$ and $\mathbf{F}$, type 3 MT; $\mathbf{G}$ and $\mathbf{H}$, bZIP transcription factor, using primers listed in Table 1. A, C, E, and $\mathbf{G}$, Amplification and $\mathbf{B}, \mathbf{D}, \mathbf{F}$, and $\mathbf{H}$, melting peak profiles of selected samples. Symbols: cDNA from velvetleaf leaves harvested $2(\bullet), 5(O)$, and $14(\boldsymbol{\nabla})$ days after Colletotrichum coccodes infection. cDNA from velvetleaf leaves mock infected and harvested $2(\nabla), 5(\mathbb{\bullet})$, and $14(\square)$ days after treatment. Negative control $=\bullet$ 
followed by a slight increase at 5 and 7 DAI. The reason why such decline occurred is unclear, but a plausible explanation is that the plant accumulated large amounts of MT transcripts in response to the pathogen within early stages of infection, and then

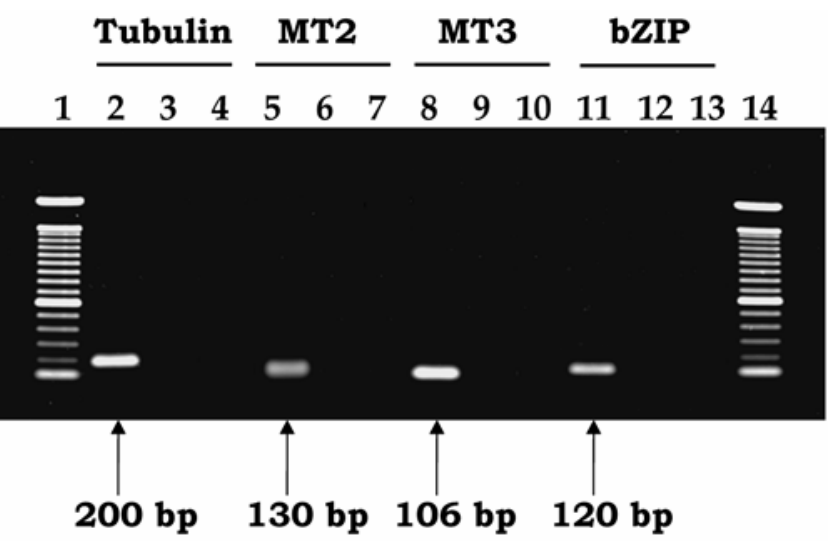

Fig. 3. Specificity of gene expression analysis by quantitative reverse-transcription polymerase chain reaction. Lanes 2 to $4=$ amplification of $\beta$-tubulin; lanes 5 to $7=$ amplification of type 2 metallothionein (MT); lanes 8 to $10=$ amplification of type $3 \mathrm{MT}$; lanes 11 to 13 = amplification of basic region/leucine zipper motif (bZIP)transcription factor using primers listed in Table 1. Lanes 2, 5, 8, and $11=$ velvetleaf cDNA; lanes $3,6,9$, and $12=$ Colletotrichum coccodes $\mathrm{cDNA}$; lanes 4, 7, 10, and $13=$ negative controls; lanes 1 and $14=100$-bp ladder. suppressed and maintained at levels comparable with those expressed in control plants. A similar trend of MT differential gene expression in tobacco plants following wounding or Tobacco mosaic virus (TMV) infection over a period of $72 \mathrm{~h}$ was observed (10). Relative amounts of MT mRNA were highly induced at $12 \mathrm{~h}$, sharply dropped after $24 \mathrm{~h}$ following wounding and TMV infection, and remained the same thereafter only for the wounding treatment.

Plant response to pathogen attack is known to be well orchestrated by transcription factors, including the ethylene-responsiveelement-binding factors, WRKY and MYB proteins, salicylic acid-inducible proteins, and bZIP proteins (38). In this study, the expression levels of velvetleaf bZIP transcription factor followed the same trend as that of type 2 and type 3 MT-like genes during the first 2 days of infection, and remained well below the levels found in uninfected plants. These results clearly suggest that velvetleaf bZIP factors responded specifically and directly to the presence of $C$. coccodes. Preferential induction of bZIP transcription factors by plant pathogens recently has been reported in pepper plants infected by bacterial and viral pathogens (27). Depending on the pathogen, northern blot experiments showed an upregulation of bZIP transcription factors as early as $3 \mathrm{~h}$ in response to pathogen inoculation, then declined 5 days after pathogen infection (27), a trend similar to what we have obtained in this study. Interestingly, in this study, the sensitivity of QRTPCR technique enabled us to detect low levels of bZIP tran-
A

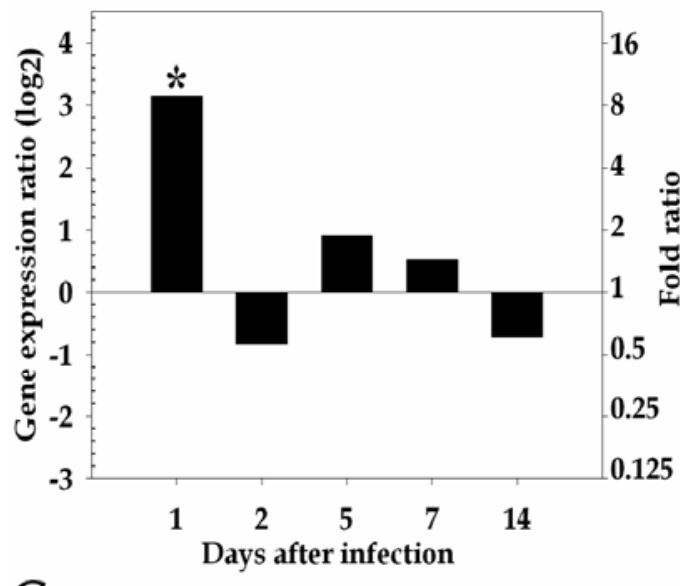

C

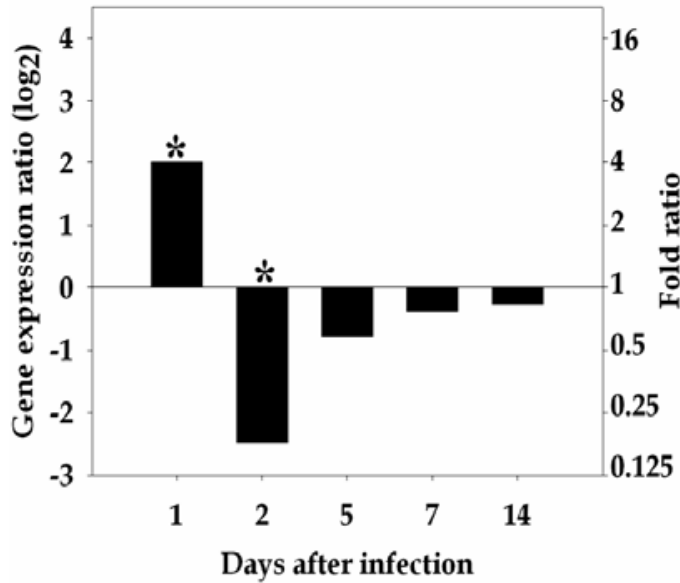

B

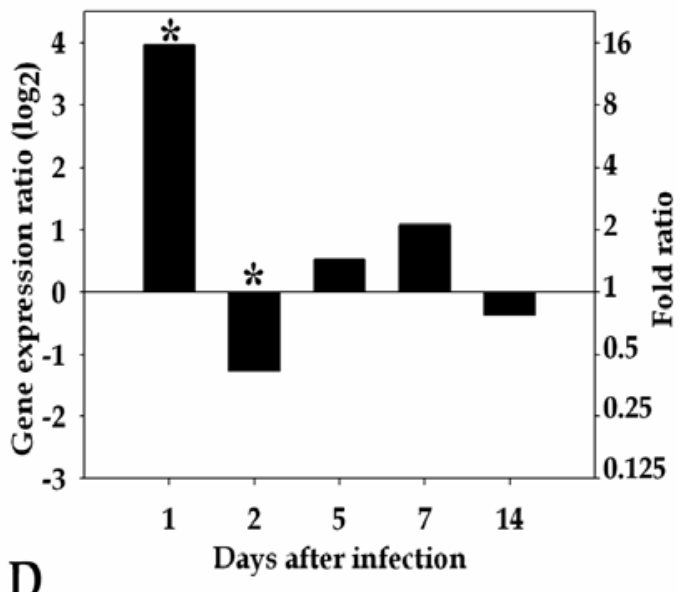

D
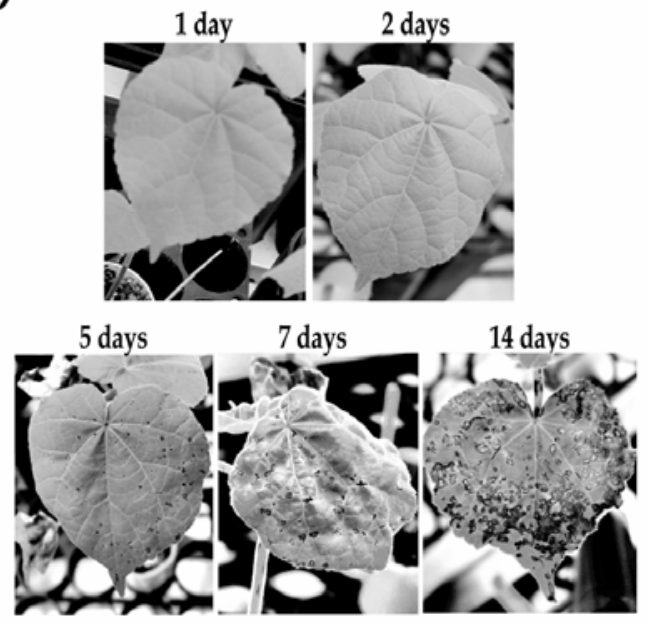

Fig. 4. Temporal expression of the type 2 and type 3 metallothionein (MT) and basic region/leucine zipper motif (bZIP) transcription factor genes in velvetleaf leaves infected with Colletotrichum coccodes. A, Type 2 MT. B, Type 3 MT. C, bZIP transcription factor. Data obtained by quantitative reverse-transcription polymerase chain reaction quantification was normalized to the $\beta$-tubulin gene expression. $Y$ axis represents the $\log _{2}$ ratio of gene expression from 1 to 14 days after fungal infection, $X$ axis represents the time points of harvest, and $*=$ significant differences of gene expression between $C$. coccodes-treated plants and control plants $(P<0.05)$; D, Velvetleaf leaves $1,2,5,7$, and 14 days after $C$. coccodes infection. 
scription factor which otherwise would not have appeared if the same data had been analyzed by northern blotting.

In conclusion, we have studied the expression of genes encoding MT types 2 and 3 and bZIP transcription factors in velvetleaf during $C$. coccodes infection, and that similar patterns of gene expression in velvetleaf occurred at $24 \mathrm{~h}$ (upregulation) and $48 \mathrm{~h}$ (downregulation) following fungal infection. After this period and depending on the gene, expression levels were maintained either below or at similar levels observed in the control treatment. Work currently is in progress to identify other genes that are tightly linked to the regulation of MT and bZIP transcription factor in response to $C$. coccodes attack. Future studies should be targeted to address the functional assessment of these genes during early and late stages of disease development of $C$. coccodes on velvetleaf, and to understand whether the function of these genes could contribute to the improvement of an effective biocontrol weed strategy.

\section{ACKNOWLEDGMENTS}

This study is supported by a Natural Science and Engineering Research Council of Canada (NSERC) Discovery Grant and the NSERC Biocontrol Network grant to S. Jabaji-Hare. We thank K. Wen for technical assistance throughout the study.

\section{LITERATURE CITED}

1. Ahn, B., Paulitz, T., Jabaji-Hare, S. H., and Watson, A. K. 2005. Enhancement of Colletotrichum coccodes virulence by inhibitors of plant defense mechanisms. Biocontrol Sci. Technol. 15:299-308.

2. Ahn, B., Paulitz, T., Jabaji-Hare, S. H., and Watson, A. K. 2005. Enzyme responses of Abutilon theophrasti in an enhanced biocontrol system. Biocontrol 50:803-817.

3. Akashi, K., Nishimura, N., Ishida, Y., and Yokota, A. 2004. Potent hydroxyl radical-scavenging activity of drought-induced type-2 metallothionein in wild watermelon. Biochem. Biophys. Res. Commun. 323:7278.

4. Altschul, S. F., Madden, T. L., Schaffer, A. A., Zhang, J. H., Zhang, Z., Miller, W., and Lipman, D. J. 1997. Gapped blast and psi-blast-a new generation of protein database search programs. Nucleic Acids Res. 25:3389-3402.

5. Amsellem, Z., Cohen, B. A., and Gressel, J. 2002. Engineering hypervirulence in a mycoherbicidal fungus for efficient weed control. Nat. Biotechnol. 20:1035-1039.

6. Bhalerao, R., Keskitalo, J., Sterky, F., Erlandsson, R., Bjorkbacka, H., Birve, S. J., Karlsson, J., Gardestrom, P., Gustafsson, P., and Lundeberg, J. 2003. Gene expression in autumn leaves. Plant Physiol. 131:430-432.

7. Breeze, E., Wagstaff, C., Harrison, E., Bramke, I., Rogers, H., Stead, A., Thomas, B., and Buchanan-Wollaston, V. 2004. Gene expression patterns to define stages of post-harvest senescence in Alstroemeria petals. Plant Biotechnol. J. 2:155-168.

8. Butt, A., Mousley, C., Morris, K., Beynon, J., Can, C., Holub, E., Greenberg, J. T., and Buchananwollaston, V. 1998. Differential expression of a senescence-enhanced metallothionein gene in Arabidopsis in response to isolates of Peronospora parasitica and Pseudomonas syringae. Plant J. 16:209-221.

9. Chen, W. Q., Provart, N. J., Glazebrook, J., Katagiri, F., Chang, H. S., Eulgem, T., Mauch, F., Luan, S., Zou, G. Z., Whitham, S. A., and Budworth, P. R. 2002. Expression profile matrix of Arabidopsis transcription factor genes suggests their putative functions in response to environmental stresses. Plant Cell 14:559-574.

10. Choi, D., Kim, H. M., Yun, H. K., Park, J. A., Kim, W. T., and Bok, S. H. 1996. Molecular cloning of a metallothionein-like gene from Nicotiana glutinosa $\mathrm{L}$. and its induction by wounding and tobacco mosaic virus infection. Plant Physiol. 112:353-359.

11. Chubatsu, L. S., and Meneghini, R. 1993. Metallothionein protects DNA from oxidative damage. Biochem. J. 291:193-198.

12. Clendennen, S. K., and May, G. D. 1997. Differential gene expression in ripening banana fruit. Plant Physiol. 115:463-469.

13. Cobbett, C., and Goldsbrough, P. 2002. Phytochelatins and metallothioneins: Roles in heavy metal detoxification and homeostasis. Annu. Rev. Plant Biol. 53:159-182.

14. Dauch, A. L., Watson, A. K., and Jabaji-Hare, S. H. 2003. Detection of the biocontrol agent Colletotrichum coccodes (183088) from the target weed velvetleaf and from soil by strain-specific PCR markers. J. Microbiol. Methods 55:51-64.
15. Dauch, A. L., Watson, A. K., Seguin, P., and Jabaji-Hare, S. H. 2006. Real-time PCR quantification of Colletotrichum coccodes DNA in soils from the bioherbicide field-release assays, with normalization for PCR inhibition by soil products. Can. J. Plant Pathol. 28:1-6.

16. DiTommaso, A., and Watson, A. K. 1995. Impact of a fungal pathogen, Colletotrichum coccodes on growth and competitive ability of Abutilon theophrasti. New Phytol. 131:51-60.

17. Droge-Laser, W., Kaiser, A., Lindsay, W. P., Halkier, B. A., Loake, G. J., Doerner, P., Dixon, R. A., and Lamb, C. 1997. Rapid stimulation of a soybean protein-serine kinase that phosphorylates a novel bZIP DNAbinding protein, $\mathrm{G} / \mathrm{HBF}-1$, during the induction of early transcriptiondependent defenses. EMBO J. 16:726-238.

18. Eulgem, T. 2005. Regulation of the Arabidopsis defense transcriptome. Trends Plant Sci. 10:71-78.

19. Gasteiger, E., Gattiker, A., Hoogland, C., Ivanyi, I., Appel, R. D., and Bairoch, A. 2003. ExPASy: the proteomics server for in-depth protein knowledge and analysis. Nucleic Acids Res. 31:3784-3788.

20. Guo, W. J., Bundithya, W., and Goldsbrough, P. B. 2003. Characterization of the Arabidopsis metallothionein gene family: Tissue-specific expression and induction during senescence and in response to copper. New Phytol. 159:369-381.

21. Hodgson, R. H., Wymore, L. A., Watson, A. K., Snyder, R. H., and Collette, A. 1988. Efficacy of Colletotrichum coccodes and thidiazuron for velvetleaf (Abutilon theophrasti) control in soybean (Glycine max). Weed Technol. 2:473-480.

22. Huang, Y. J., To, K. Y., Yap, M. N., Chiang, W. J., Suen, D. F., and Chen, S. C. G. 2001. Cloning and characterization of leaf senescence upregulated genes in sweet potato. Physiol. Plant. 113:384-391.

23. Jakoby, M., Weisshaar, B., Droge-Laser, W., Vicente-Carbajosa, J., Tiedemann, J., Kroj, T., and Parcy, F. 2002. bZIP transcription factors in Arabidopsis. Trends Plant Sci. 7:106-111.

24. Kim, H. S., and Delaney, T. P. 2002. Over-expression of TGA5, which encodes a bZIP transcription factor that interacts with NIM1/NPR1, confers SAR-independent resistance in Arabidopsis thaliana to Peronospora parasitica. Plant J. 32:151-163.

25. Kohler, A., Blaudez, D., Chalot, M., and Martin, F. 2004. Cloning and expression of multiple metallothioneins from hybrid poplar. New Phytol. 164:83-93.

26. Laplaze, L., Gherbi, H., Duhoux, E., Pawlowski, K., Auguy, F., Guermache, F., Franche, C., and Bogusz, D. 2002. Symbiotic and nonsymbiotic expression of Cgmtl, a metallothionein-like gene from the actinorhizal tree Casuarina glauca. Plant Mol. Biol. 49:81-92.

27. Lee, S. J., Lee, M. Y., Yi, S. Y., Sang, K. H., Choi, S. H., Her, N. H., Choi, D., Min, B. W., Yang, S. G., and Harn, C. H. 2002. PPI1: A novel pathogen-induced basic region-leucine zipper (bZIP) transcription factor from pepper. Mol. Plant-Microbe Interact. 15:540-548.

28. Lee, W., Haslinger, A., Karin, M., and Tjian, R. 1987. Activation of transcription by two factors that bind promoter and enhancer sequences of the human metallothionein gene and SV40. Nature 325:368-372.

29. Lin, J., and Wu, S. 2004. Molecular events in senescing Arabidopsis leaves. Plant J. 39:612-628.

30. Mir, G., Domenech, J., Huguet, G., Guo, W. J., Goldsbrough, P., Atrian, S., and Molinas, M. 2004. A plant type 2 metallothionein (MT) from cork tissue responds to oxidative stress. J. Exp. Bot. 55:2483-2493.

31. Miura, T., Muraoka, S., and Ogiso, T. 1997. Antioxidant activity of metallothionein compared with reduced glutathione. Life Sci. 60:301-309.

32. Palmiter, R. D. 1998. The elusive function of metallothioneins. Proc. Natl. Acad. Sci. USA 95:8428-8430.

33. Pfaffl, M. W. 2001. A new mathematical model for relative quantification in real-time RT-PCR. Nucleic Acids Res. 29:2002-2007.

34. Quirino, B. F., Normanly, J., and Amasino, R. M. 1999. Diverse range of gene activity during Arabidopsis thaliana leaf senescence includes pathogen-independent induction of defense-related genes. Plant Mol. Biol. 40:267-278.

35. Reid, S. J., and Ross, G. S. 1997. Up-regulation of two cDNA clones encoding metallothionein-like proteins in apple fruit during cool storage. Physiol. Plant. 100:183-189.

36. Rozen, S., and Skaletsky, H. J. 2000. Primer3 on the www for general users and for biologist programmers. In: Bioinformatics Methods and Protocols: Methods in Molecular Biology. Humana Press, Totowa, NJ.

37. SAS Institute, I. 1989. SAS/STAT User's Guide, 4th ed., vol. 2, version 6. SAS Institute Inc., Cary, NC.

38. Singh, K. B., Foley, R. C., and Onate-Sanchez, L. 2002. Transcription factors in plant defense and stress responses. Curr. Opin. Plant Biol. 5:430-436.

39. Thatcher, L. F., Anderson, J. P., and Singh, K. B. 2005. Plant defence responses: What have we learnt from Arabidopsis? Funct. Plant Biol. 32:1-19.

40. Thomas, J. C., Perron, M., LaRosa, P. C., and Smigocki, A. C. 2005. Cytokinin and the regulation of a tobacco metallothionein-like gene during copper stress. Physiol. Plant. 123:262-271. 
41. Watson, A. K., Gressel, J., Sharon, A., and Dinoor, A. 2000. Colletotrichum strains for weed control. In: Colletotrichum: Host Specificity, Pathology, and Host-Pathogen Interaction. The American Phytopathological Society, St. Paul, MN.

42. Weisshaar, B., Armstrong, G. A., Block, A., Da Costa e Silva, O., and Hahlbrock, K. 1991. Light-inducible and constitutively expressed DNAbinding proteins recognizing a plant promoter element with functional relevance in light responsiveness. EMBO J. 10:1777-1786.

43. White, C. N., and Rivin, C. J. 1995. Characterization and expression of a cDNA encoding a seed-specific metallothionein in maize. Plant Physiol. 108:831-832.

44. Wong, H. L., Sakamoto, T., Kawasaki, T., Umemura, K., and Shimamoto, K. 2004. Down-regulation of metallothionein, a reactive oxygen scavenger, by the small GTPase OsRac1 in rice. Plant Physiol. 135:14471456
45. Wymore, L. A., and Watson, A. K. 1989. Interaction between a velvetleaf isolate of Colletotrichum coccodes and thidiazuron for velvetleaf (Abutilon theophrasti) control in the field. Weed Sci. 37:478-483.

46. Yang, S., Yamaguchi, Y., Koizumi, N., Kusano, T., and Sano, H. 2002. Promoter analysis of tbzF, a gene encoding a bZIP-type transcription factor, reveals distinct variation in cis-regions responsible for transcriptional activation between senescing leaves and flower buds in tobacco plants. Plant Sci. 162:973-980.

47. Yu, X., Hallet, S. G., Sheppard, J., and Watson, A. K. 1997. Application of the Plackett-Burman experimental design to evaluate nutritional requirements for the production of Colletotrichum coccodes spores. Appl. Microbiol. Biotechnol. 47:301-305.

48. Zhou, G. K., Xu, Y. F., and Liu, J. Y. 2005. Characterization of a rice class II metallothionein gene: Tissue expression patterns and induction in response to abiotic factors. J. Plant Physiol. 162:686-696. 